Jurnal Teknologi, 39(E) Dis. 2003: 47-61

(C) Universiti Teknologi Malaysia

\title{
KETAMADUNAN MELAYU DAN SAINS: SATU ANALISIS AWAL KE ATAS PENCAPAIAN MASYARAKAT MELAYU DALAM BIDANG SAINS
}

\author{
MOHD KOHARUDDIN MOHD BALWI*
}

\begin{abstract}
Abstrak. Kertas ini merupakan satu usaha untuk meneroka dan mendedahkan pencapaian masyarakat Melayu dalam bidang sains sebelum masyarakat Melayu mengenal ilmu sains moden daripada Barat. Terdapat tiga pencapaian sains yang diteliti iaitu pencapaian sains dalam bidang perubatan, matematik dan kimia (peleburan logam). Perkembangan ketiga-tiga bidang ini banyak dipengaruhi oleh kepentingannya dalam kehidupan seharian masyarakat Melayu. Perkembangan ilmu sains Melayu juga berlaku terutama apabila mereka memeluk agama Islam pada abad ke 7 masihi. Bermula dari detik itu sebahagian tradisi keilmuan Melayu mengongsi tradisi keilmuan dari umat Islam lain. Ilmu-ilmu ini kemudiannya diubahsuai dan diperbaiki oleh para cerdik pandai tempatan untuk digunakan dalam kehidupan masyarakat Melayu. Terdapat juga cerdik pandai tempatan ini yang menghasilkan ilmu-ilmu sains baru bagi menyelesaikan permasalahan seharian masyarakat dari masa ke semasa.
\end{abstract}

Kata kunci: Tamadun, Melayu, sains, pengubatan, matematik, kimia

Abstract. This paper want to explores and reveals the achievement of Malay Society in science, expecially before western modern science was introduced in Malay civilization. Three Malay achievements in sciences; medicine, mathematics and chemistry were studied. The progress of Malay science was determined not only by its importance in the daily lives of the people but also by Islamic civilization after the Malays embraced Islam in the seventh century. Science knowledge had been absorbed and adapted by the local geniuses. They also produced new knowlege and practices to overcome various problems which they faced from time to time.

Keywords: Civilization, Malay, science, medicine, mathematics, chemistry

\subsection{PENDAHULUAN}

Pengertian sains yang akan diguna pakai dalam melihat pencapaian sains masyarakat Melayu adalah pengertian sains yang luas berasaskan kepada pengertian sains sebagai ilmu pengetahuan atau singkatnya ilmu. Perkataan sains itu berasal daripada science dalam bahasa Inggeris atau dalam bahasa Latin scientia, yang bermaksud pengetahuan (Wan Fuad Wan Hassan, 1996). Pengertian pengetahuan di sini adalah pengetahuan yang khusus atau mempunyai ciri-ciri, tanda-tanda dan syarat-syarat yang khas. Sains lebih dikenal sebagai perbendaharaan ilmu (Wan Fuad Wan Hassan, 1996). Pengertian

* Jabatan Pembangunan Sumber Manusia, Fakulti Pengurusan \& Pemb. Sumber Manusia Universiti Teknology Malaysia, 81310 Skudai, Johor Darul Ta'zim. 
ini dipakai oleh Tamadun Islam dan Tamadun Barat sebelum berlakunya revolusi sains Barat pada hari ini yang melihat sains itu dari kaca mata barat yang amat jauh bezanya dengan pengertian sains yang asal. Sains moden hari ini juga disebut sebagai sains barat (Wan Fuad Wan Hassan, 1996). Pengertian sains Melayu yang digunakan untuk mengenalpasti sains Melayu ialah ilmu atau pengetahuan yang mempunyai ciriciri, tanda-tanda dan syarat-syarat khas. Ia juga melibatkan pengetahuan bersistem yang diperolehi daripada cerapan, kajian dan eksperimen. Bagaimanapun cerapan, kajian dan eksperimen itu bukanlah sebagaimana yang kita fahami hari ini sebaliknya cerapan, kajian dan eksperimen yang telah dilakukan melalui pengalaman budaya Melayu. Dalam bidang perubatan misalnya masyarakat Melayu juga melalui pengalaman selama ratusan tahun melakukan kajian dan eksperimen sehingga mereka boleh menghasilkan pelbagai teknik dan pengetahuan pengubatan. Dalam kertas ini sains Melayu di bahagikan kepada tiga iaitu sains perubatan Melayu, ilmu Matematik dan kimia (peleburan logam).

\subsection{PERUBATAN MELAYU}

Masyarakat Melayu memiliki pengetahuan yang mendalam dalam usaha pemulihan daripada sakit-demam dan keuzuran. Sebelum kedatangan pengubatan moden, orang Melayu bergantung sepenuhnya kepada pengubatan tradisional Melayu ini. Apabila pengubatan moden gagal mengubati keuzuran atau sakit yang dihidapi oleh orang Melayu mereka akan kembali merujuk kepada pengubatan tradisional. Dengan kata lain kebergantungan orang Melayu dengan warisan perubatan tradisional ini masih lagi berlanjutan hingga ke hari ini.

\subsection{Kitab atau Buku Perubatan Melayu}

Beberapa kaedah merawat pesakit ada diterangkan dalam buku-buku perubatan Melayu atau lebih dikenal sebagai kitab-kitab tib. Perkataan tib berasal dari bahasa Arab yang bermaksud ubat, tukang ubat dan ilmu perubatan. Ada pelbagai kitab tib yang digunakan oleh orang Melayu. Kandungan kitab-kitab ini merangkumi penerangan mengenai penyakit-penyakit biasa seperti demam, batuk dan lelah. Selain itu kitab tib menerangkan penyakit yang berpunca daripada rasukan hantu, syaitan dan jin yang disertai dengan jampi mantera. Bentuk pengubatan dan rawatannya mengandungi doa-doa, ayat al-Quran, hadis, tangkal dan azimat. Rajah dan kata-kata tertentu turut disertakan.

Antara Kitab Tib yang terkenal ialah Taj-ul-Muluk, dan ada juga yang menamakannya sebagai Kitab Mujarrabat Melayu (Mohd Taib Osman, 1988). Kitab tib ini mengandungi 500 muka surat yang berkaitan 147 perkara atau fasal. Terdapat fasal yang menerangkan pengetahuan pengubatan, cara berhubung dengan ilmu sihir dan kaedah atau ritual pengubatan. 
Terdapat sebuah buku perubatan Melayu yang telah diterjemahkan ke dalam bahasa Inggeris pada tahun 1886. Buku tersebut berjudul This is The Medical Book of Malayan Medicine yang kini dimiliki oleh The Pharmaceutical Society of Great Britain. Menurut editornya sejarah penterjemahan buku tersebut tidak diperolehi atau hilang dan buku tersebut ditulis tangan oleh penterjemahnya bernama Ismail Munsyi. Ia telah diedit semula oleh Gimlette (Zhari Ismail dan Norhayati Ismail, 1995). Salah satu daripada preskri psi yang terdapat dalam buku perubatan Melayu ini (no. 99) telah digunakan sebagai ubat untuk melegakan lelah dan bronkitis di Barat pada sekitar tahun 1915. Ia satu pengiktirafan secara tidak langsung terhadap ubat-ubatan Melayu oleh orang Barat pada ketika itu.

Selain itu terdapat juga manuskrip lama yang bertajuk Ilmu Tabib yang bertarikh 1288 hijrah. Buku ini telah disalin dengan tulisan tangan yang baik oleh Muhammad Saleh bin Ahmad Penambang dari Kelantan. Ia tertulis jampi mantera yang disertai dengan atau tanpa penggunaan ubat-ubatan (A. Samad Ahmad, 1988). Kini ia dimiliki oleh Dewan Bahasa dan Pustaka.

Secara ringkasnya buku perubatan Melayu atau kitab tib Melayu meliputi di antaranya:
a. Taj-ul-Muluk
b. Kitab Mujarrabat Melayu
c. This is The Medical Book of Malayan Medicine
d. Ilmu Tabib

\subsection{Punca Sakit-demam atau Keuzuran}

Terdapat dua penyebab keuzuran atau sakit dalam masyarakat Melayu. Pertama, disebabkan oleh faktor fizikal seperti keadaan persekitaran dan fisiologi manusia itu sendiri dan kedua, disebabkan faktor kuasa supernatural seperti pengaruh ilmu sihir dan makhluk halus. Penjenisan ini boleh diklasifikasikan kepada dua bentuk etiologi atau penjenisan sakit demam iaitu pertama, berbentuk naturalistik dan personalistik. Naturalistik melihat sakit demam berpunca daripada gangguan faktor alam seperti sejuk, panas, angin dan lain-lain gangguan yang menyebabkan keseimbangan unsurunsur asas dalam badan terganggu. Sebaliknya etiologi personalistik berkaitan dengan sakit-demam atau keuzuran yang berkaitan dengan gangguan agen, yang mungkin pertama, terdiri daripada manusia, iaitu ahli sihir, kedua bukan manusia atau hantu dan seumpamanya dan ketiga daripada kuasa luar biasa misalnya Tuhan (Hashim Awang A. R. 1990).

Perubatan Melayu yang berbentuk naturalistik menganggap bahawa manusia perlulah mempunyai keseimbangan dalam semua unsur yang terdapat dalam badan manusia. Dalam kitab perubatan Melayu atau kitab tib Melayu meletakkan bahawa manusia dijadikan daripada empat unsur atau anasir. Empat anasir itu ialah tanah, air, api dan angin (Hashim Awang A. R. 1990). Setiap anasir mempunyai perangainya 
yang tersendiri. Perangai tanah dingin dan kering; api panas dan kering; air dingin serta basah dan angin panas serta basah. Perimbangan keempat-empat anasir itu penting kerana kesihatan seseorang bergantung kepada perimbangan tersebut. Apabila perimbangan antara anasir-anasir terganggu, kesihatan seseorang akan turut terganggu.

Faktor yang paling kuat yang boleh mengganggu perimbangan tadi antaranya ialah makanan. Lantaran itu mereka amat berhati-hati dengan pengambilan makanan. Selaras dengan itu orang Melayu percaya makanan boleh dijeniskan mengikut kesannya ke atas badan seseorang. Ada makanan yang dijeniskan sebagai panas, ada yang sejuk, ada yang berangin dan ada yang bisa (Hashim Awang A. R. 1990). Pengambilan mana-mana jenis makanan secara berlebihan akan mengganggu perimbangan anasir badan. Pengambilan makanan yang dianggap makanan panas yang berlebihan boleh mengakibatkan ketidak-seimbangan dalam badan hingga boleh membawa pening kepala dan demam. Dari itu memakan makanan yang betul boleh mengekalkan keharmonian unsur sejuk dan panas dalam badan seterusnya mengekalkan kesihatan. Pengkelasan ini juga merupakan kerangka bagi menentukan apa yang boleh dimakan dan tidak boleh dimakan, dalam keadaan bagaimana sesuatu bahan makanan itu boleh dimakan, apakah akibat yang timbul sekiranya peraturan makanan ini tidak dipatuhi, dan rawatan yang perlu digunakan apabila tersalah makan. Makanan yang dipercayai memiliki unsur panas tidak elok dimakan pada waktu tengah hari, bersaingan dengan pengambilan sesuatu ubat atau apabila mengidap penyakit yang diketagorikan sebagai panas. Penyakit yang diakibatkan oleh memakan makanan yang panas secara berle-bihan memerlukan makanan atau rawatan yang bersifat sejuk. Begitulah sebaliknya.

Makanan yang dikelaskan sebagai makanan panas ialah makanan yang mengandungi lemak sama ada jenis lemak binatang atau lemak sayur-sayuran, tonik, rempah (jintan, ketumbar, lengkuas), tuak; protein binatang (ayam, kambing, lembu dan kerbau; susu dan telur); makanan masin (garam dan ikan kering); makanan yang mempunyai rasa pahit (peria); dan rasa pedas (cili). Makanan yang diketagorikan sebagai sejuk terdiri daripada buah-buahan dan sayur-sayuran yang mempunyai ciriciri seperti berair (mentimun, tembikai, nanas dan limau), berlendir (kacang bendi, keladi dan pucuk paku), bergetah (bacang, mangga muda, nangka, cempedak dan jantung pisang), masam (mangga dan kedondong), menjalar (kangkung, labu dan kacang panjang) (Aishah Haji Muhammad, 1998).

Mereka juga mengkategorikan makanan sebagai gatal seperti makanan laut ; udang, ketam, sotong, kerang dan beberapa jenis ikan yang mempunyai ciri-ciri seperti warna kemerah-merahan dan kekuning-kuningan, tulang halus dan bersisik. Terdapat juga makanan yang dianggap mengandungi unsur bisa yang boleh membawa kesan yang tidak baik kepada seseorang yang sedang sakit seperti telur, lemak dan beberapa jenis ikan, makanan ini tidak dibenarkan dimakan sekiranya seseorang itu mengalami luka, penyakit kulit atau dalam pantang kerana dipercayai boleh menyebabkan rahim menjadi bernanah dan lambat sembuh (Aishah Haji Muhammad, 1998). 
Selain itu orang Melayu juga percaya peranan angin dalam badan, jika kandungan angin terlalu banyak boleh menyebabkan sakit. Makanan berangin ini terdiri daripada nangka, cempedak, ubi kayu, keledek dan labu. Di samping itu dalam masyarakat Melayu mereka mengenali punca penyakit daripada kuman yang ada di persekitaran fizikal mereka.

\subsection{Kegiatan dan Teknik Penyembuhan}

Setiap masyarakat mempunyai teknik penyembuhan yang tersendiri. Masyarakat Melayu mempunyai beberapa cara penyembuhan yang melibatkan proses diagnosa dan teknik rawatan. Diagnosa atau mengenalpasti penyakit dilakukan dengan dua kaedah iaitu personalistik dan naturalistik. Pakar perubatan yang terlibat terutamanya bomoh akan melakukan kedua-dua teknik ini. Diagnosa naturalistik misalnya dengan merasa denyutan nadi, memeriksa kulit, permukaan lidah, mata, perut, darah, telinga, kahak dan seumpamanya. Diagnosa personalistik pula dilakukan dengan cara menurun atau trance iaitu bomoh meminta bantuan kuasa luar biasa. Teknik ini disebut juga sebagai pengubatan shamanistik. Contoh pengubatan cara ini ialah Main Peteri.

Teknik rawatan pula meliputi pembedahan misalnya bekam dan khatan, urut, penggunaan ubat-ubatan yang pelbagai jenis seperti daripada akar kayu dan jamu. Selain itu teknik rawatan juga melibatkan teknik pengelakan dengan pesakit dikenakan berbagai-bagai pantang larang.

Pengubatan tradisional atau bahan-bahan 'penawar' pula berdasarkan flora dan fauna yang mudah diperolehi daripada hutan. Pengubatan cara ini dipanggil ubat akar kayu. Di kalangan Masyarakat Melayu, penggunaan ramuan atau ubat akar kayu masih popular hingga ke hari ini. Orang Melayu percaya ubat akar kayu ini mempunyai khasiat yang tinggi dan mampu mengubati banyak penyakit. Akar kayu bermaksud segala ramuan yang diperbuat daripada bahagian-bahagian tumbuhan seperti daun, bunga, batang, kulit dan juga akar kayu. Terdapat lebih kurang 6000 sehingga 7000 spesies tumbuhan peringkat tinggi yang digunakan sebagai bahan untuk ubat akar kayu oleh pakar perubatan Melayu. Selain itu tumbuhan ini boleh juga diperolehi di sekeliling kampung atau halaman rumah.

Tumbuh-tumbuhan yang mempunyai nilai perubatan di kalangan orang Melayu ini terdiri dari pada famili angiosperma, leguminosea, rubiacoae, euphorbiacoae, rutcaea dan lauraceau (Aishah Haji Muhammad, 1998). Bahan-bahan ini digunakan secara berbeza untuk mengubati penyakit luaran dan penyakit dalaman. Penyakit luaran seperti kudis, luka, panau dan seumpamanya. Penyakit dalaman pula kembung perut, cirit birit, sembelit, angin dan sebagainya. Contoh tumbuhan yang boleh diguna sebagai ubat ialah kunyit untuk mengubati luka. Bahan lain yang diguna antaranya terdiri daripada rempah ratus seperti jintan manis, jintan putih, lada hitam, lada putih, kayu manis, bunga cengkih, bunga lawang, buah pegaga, halia bara dan halia hidup. Di samping sebagai bahan untuk pengubatan ia juga digunakan sebagai perencah 
masakan. Selalunya pengambilan pengubatan akar kayu ini disertai oleh pantang larang tertentu yang perlu dipatuhi untuk memastikan kemujaraban ubat tersebut.

Antara kemajuan ubat-ubatan Melayu tradisional ini ialah adanya penawar atau antidot untuk beberapa jenis kes keracunan. Terdapat bahan-bahan untuk merangsangkan muntah (emetik) yang digunakan oleh para pengamal atau pakar perubatan Melayu sejak dahulu dan kini dalam perubatan Barat moden. Selain dari ubatan yang dibuat daripada tumbuhan terdapat juga ubatan yang dibuat dari pada haiwan seperti hempedu gajah, hempedu sawa, lemak landak, tulang sotong dan seumpamanya (Zhari Ismail \& Norhayati Ismail, 1995).

Pada masa kini ubat-ubatan atau materia medika ini telah diformulasikan ke dalam pelbagai bentuk penyediaan seperti bentuk keratan kecil, serbuk, kapsul bagi yang pepejal, bentuk pil (bebola kecil) bagi yang separa pepejal seperti makjun dan bagi yang cecair berbentuk seperti tonik dan berbagai-bagai ekstrak cecair. Bagi ubat yang digunakan di bahagian luar seperti kulit dan muka terdapat penyediaan berbentuk salap, param dan seumpamanya.

Selain kaedah rawatan ubat-ubatan, kaedah rawatan juga melibatkan kaedah atau teknik pembedahan. Terdapat tiga teknik pembedahan iaitu bersunat, berbekam dan memulihkan tulang patah. Berbekam satu cara mengeluarkan darah yang dipercayai kotor daripada badan. Berbekam dilakukan di bahagian belakang atau tempurung kepala dengan menggunakan peralatan-peralatan tertentu seperti gelas, tanduk dan pisau. Tujuan berbekam adalah untuk menghilangkan atau mengurangkan rasa sakit kepala, sakit pinggang, lutut dan kaki yang dipercayai akibat angin yang berlebihan dalam badan. Terdapat tiga jenis berbekam iaitu bekam angin, bekam tanduk dan bekam api. Bekam tanduk digunakan untuk mengeluarkan darah kotor, bekam angin untuk mengeluarkan angin penyakit dan bekam api untuk mengeluarkan angin sejuk.

Patah tulang sering dirujuk kepada bomoh tulang. Masyarakat Melayu lebih yakin dengan keupayaan kaedah tradisional berbanding moden dalam memulihkan patah tulang. Selain dikenali sebagai bomoh tulang mereka juga dikenali sebagai bomoh patah. Kaedah yang digunakan ialah urutan ke atas bahagian yang sakit dengan disertai bacaan tertentu yang sering diambil daripada al-Quran. Pembacaan al-Quran ini juga meliputi sebahagian usaha penyembuhan kerana masyarakat Melayu percaya dengan peranan jampi serapah dan doa. Misalnya tujuan utama doa dibaca sewaktu memulihkan pesakit ialah untuk memohon restu Allah Taala yang terdiri daripada ayat-ayat suci al-Quran dan selawat kepada Nabi Muhammad s.a.w.

\subsection{Pakar Perubatan Melayu}

Terdapat tokoh tertentu yang sangat dihormati dalam masyarakat kerana kepandaiannya dalam mengubati sakit demam dan keuzuran ini. Mereka ini dipanggil bomoh, pawang, dukun, tok puteri, tukang urut, tukang bekam, tok mudim dan bidan (Zhari Ismail \& Norhayati Ismail, 1995). Panggilan yang paling popular sekali ialah bomoh. 
Bomoh mengendalikan perkara yang berkaitan keuzuran yang diakibatkan oleh faktor fizikal dan juga faktor supernatural.

Kebanyakannya bertindak sebagai pakar perubatan Melayu secara persendirian atau individu berbanding pawang yang dikenali sebagai pakar pengubatan Melayu yang berperanan kumunal yang melibatkan seluruh penduduk kampung. Perkataan bomoh itu sendiri kadang-kadang merangkumi keseluruhan tokoh perubatan yang lain seperti dukun, pawang atau bidan. Bagaimanapun sebenarnya terdapat perbezaan kecil antara panggilan-panggilan itu. Pawang lebih banyak terlibat dalam hal-hal berkaitan makhluk halus seperti upacara penanaman padi dan penuaian padi yang melibatkan upacara secara besar-besaran di sesuatu kampung. Pada masa sekarang keadaan seperti ini tidak lagi diamalkan. Bomoh atau pawang ini menjadi perantara antara manusia dengan segala makhluk ghaib ini. Bomoh biasanya mempunyai kepakaran atau pun pengkhususan yang tersendiri. Berdasarkan pengkhususan itu bomoh boleh dibahagikan kepada beberapa jenis. Antaranya ialah bomoh patah, bomoh urut, bomoh ular, bomoh akar kayu dan berbagai-bagai lagi.

Tugas bomoh bukan sahaja terbatas kepada kegiatan penyembuhan, tetapi juga meliputi kegiatan-kegiatan pencegahan, iaitu memberikan petua-petua untuk mengelakkan seseorang itu ditimpa sakit-demam atau keuzuran. Seseorang itu menjadi bomoh dengan beberapa cara antaranya melalui menuntut dan mimpi. Cara menuntut ialah dengan mempelajari ilmu daripada seorang guru, melalui sesuatu pengalaman istimewa, misalnya mewarisi daripada ayah atau keluarga yang rapat yang pernah menjadi bomoh (keturunan). Melalui mimpi pula lebih kepada bentuk luar biasa iaitu kepandaian dan kuasa mengubati diperolehi melalui mimpi; mendapat kembaran atau makhluk luar biasa yang dipelihara misalnya akuan atau berpolong; penurunan dengan kuasa luar biasa secara kebetulan selalunya waktu sakit atau tidak sedarkan diri atau apabila seseorang itu mendapat sesuatu benda ajaib yang mempunyai kuasa magis seperti geliga ular dan seumpamanya (Mohd Taib Osman, 1977).

Dukun dan bidan merupakan panggilan orang Melayu kepada mereka yang pandai mengubati penyakit secara pengubatan fizikal sama ada dengan menggunakan bahanbahan ubatan yang diambil daripada sumber flora dan fauna seperti akar kayu dan daunan atau pengubatan melalui urutan ke atas badan pesakit. Tugas utama bidan ialah untuk mengendalikan kelahiran bayi, juga bertanggungjawab terhadap kesihatan ibu semasa mengandung dan semasa berada dalam pantang. Secara ringkas bidan berusaha untuk mencegah berlakunya keguguran, kecederaan kepada bayi dalam kandungan, komplikasi selepas bersalin atau mengambil langkah-langkah untuk mengelakkan ibu dan bayi daripada serangan sakit-demam. Tok Mudim pula ialah tokoh perubatan yang mahir melakukan upacara berkhatan untuk kanak-kanak lelaki. Upacara berkhatan bagi kanak-kanak perempuan dilakukan oleh bidan. Dengan kata lain bidan ialah pakar dalam mengendalikan segala urusan berkaitan masalah keuzuran wanita. 
Dalam keadaan tertentu segala istilah kepakaran perubatan Melayu ini bertindan untuk seseorang tokoh tertentu. Seseorang itu boleh menjadi bomoh dan dalam masa yang sama juga boleh berperanan sebagai tok mudim. Bagi masyarakat Melayu hari ini yang mengalami arus pemodenan, mereka menerima pengubatan moden yang dikendalikan oleh doktor perubatan moden. Bagaimanapun apabila pengubatan moden gagal dalam mengatasi sakit dan keuzuran, orang Melayu akan mengalihkan perhatian semula kepada pengubatan tradisional yang lebih dikenal sebagai 'pengubatan kampung'.

\subsection{MATEMATIK}

Kepentingan matematik terjelma dalam sejarah perkembangan tamadun Melayu itu sendiri. Kepulauan Melayu pernah menjadi pusat perdagangan yang utama di dunia. Di sini berlakunya urusan perniagaan yang tentunya memerlukan kebolehan mengira yang baik. Urusan perniagaan timbang-menimbang, sukat menyukat, tukar-menukar mata wang, cukai, dan seumpamanya memerlukan pengiraan yang sistematik.

Di samping itu dalam kehidupan seharian masyarakat Melayu banyak contoh yang menunjukkan konsep pengiraan menjadi sebahagian daripada budaya mereka. Orang Melayu terkenal sebagai ahli pertukangan yang mahir, terlibat dalam pembinaan masjid, rumah kediaman, kapal layar dan perahu. Pelayaran juga menjadi perkara utama dalam kehidupan mereka yang juga memerlukan kepakaran dalam bidang matematik.

Pencapaian orang Melayu dalam bidang matematik banyak dipelopori oleh tokohtokoh agama yang menjadi guru atau ulama dalam institusi pendidikan yang dipanggil pondok di Malaysia atau pesantren di Indonesia. Kebanyakan tokoh ini mendapatkan ilmu tentang matematik melalui pengajian mereka di Asia Tengah. Apabila mereka pulang ke tanah air, mereka mengembangkan ilmu ini dengan melakukan penambahbaikan dan pembaharuan dengan menulis pelbagai kitab atau buku berkaitan matematik. Buku-buku ini digunakan sebagai teks dalam pengajian tradisi.

Hingga kini tidak ramai yang sedar bahawa ramai ulama Melayu yang menulis tentang matematik atau lebih dikenal sebagai ilmu hisab. Mereka menulis tentang Hisab al-Hind, aljabar, geometri, logaritma dan falak. Perkembangan matematik Melayu adalah satu cabang daripada lanjutan perkembangan matematik Islam tamadun Islam. Sebelum matematik barat diperkenalkan di rantau ini matematik Islam telah mendahului dalam sistem pendidikan tradisinya. Antara cabang matematik tersebut ilmu falaklah yang menjadi warisan terbesar yang ditinggalkan oleh penulis Melayu silam (Mat Rofa Ismail, 1996).

\subsection{Tokoh Matematik dan Karya Mereka}

Antara tokoh prolifik yang menulis dalam bidang ini ialah: 

a. Syeikh Abdul Rahman Muhammad al-Fatani
b. Syeik Ahmad al-Fatani
c. Syeikh Ahmad bin Abdul Latif al-Khatib al-Minangkabawi
d. Syeikh Tahir Jalaluddin Perak
e. Syeikh Muhammad Ali Abdul Mutalib al-Minkabawi

Antara karya mereka itu adalah:

a. Syeikh Ahmad 'Abdul Latif al-Khatib. (Raudat al-Hussab fi a'mal al-Hisab, al Nukhbah al-bahiyyah, al-Jawahir al-Naqiyyah)

b. Syeikh 'Abdul Rahman Muhammad al-Fatani. (Minhaj al-Qawim pada mengetahui hisab dan taqwim)

c. Syeikh Ahmad al-Fatani (Ilmu Hisab dan Ilmu Falak)

d. Haji Umar Nuruddin (Miftah al-Ta'lim, al-Durr al-naqiyy fi ma'rifat arqam al-Hindi, Syams al-Fathiyyah)

e. Syeik Tahir Jalaluddin (Pati kiraan pada menentukan waktu yang lima dengan hal kiblat dengan logaritma)

f. Ilmu Hitungan, Ilmu Falak, Masalah Ilmu Bumi, Hitungan gedang dan Hitungan Kecil. ( terdapat dalam simpanan atau koleksi J.A.W. Van Ophuysen, Belanda.)(Mat Rofa Ismail, 1996).

\subsection{Bidang Matematik dan Kegunaannya dalam Masyarakat Melayu}

Islam menentukan semua bentuk kehidupan harian manusia, maka secara langsung masyarakat Melayu terikat dengan peraturan yang terkandung di dalam ajarannya. Kebanyakan kegunaan matematik pula penting dalam hubungannya dengan pengamalan ajaran Islam itu sendiri. Di samping itu ajaran Islam sangat menitikberatkan soal ketepatan dalam beribadat seperti ibadat sembahyang, puasa, zakat, haji, pewarisan, jual beli dan seumpamanya.

Peranan matematik juga sangat penting dalam dunia ilmiah Islam. Dalam pengkelasan ilmu-ilmu Islam para ilmuan telah menyenaraikan ilmu-ilmu mengikut hierarki kepentingan yang didasarkan kepada pengkelasan fardu 'ain, fardu kifayah, ilmu-ilmu alat dan ilmu-ilmu penyokong. Ilmu-ilmu yang bersumberkan wahyu dianggap ilmu-ilmu utama dalam pengajian tradisi, manakala ilmu-ilmu lain adalah sebagai ilmu penyokong atau tambahan. Ilmu saraf, mantik dan matematik termasuk dalam ilmu alat atau ilmu pengantar. Dalam keadaan ini matematik atau tajuk tertentu dalam pelbagai cabangnya dikaji dan diulas bersama-sama ilmu lain secara bersepadu dalam sistem tersebut. Ilmu matematik ini dikaji dan dipelajari kerana kepentingannya dalam kehidupan seharian masyarakat Melayu yang sebahagian besarnya beragama Islam. 
Berikut ialah antara ilmu yang melibatkan matematik dan kepentingannya:

Ilmu aljabar: digunakan dalam pengiraan zakat, sewa menyewa, wasiat, perkongsian, pajak gadai, riba, faraid dan seumpamanya yang berkaitan dengan fekah dan hukum agama. Ilmu ini juga digunakan dalam kehidupan seharian seperti pengiraan perniagaan, pertukaran wang, timbang-menimbang dan sebagainya.

Ilmu falak: ilmu ini penting dalam menentukan penentuan awal Ramadan dan Syawal, perjalanan matahari termasuk pengiraan waktu sembahyang, gerhana bulan dan matahari, kedudukan bintang Thabitah dan sayyarah, galaksi dan seumpamanya. Ilmu Geometri dan Trigonometri digunakan dalam mengira dan menentukan arah kiblat, masalah koordinat sesebuah bandar, masalah yang berkaitan sfera bumi, kompas perjalanan dan pelayaran. Kajian dalam bidang geometri ini ada dilakukan oleh Syeikh Ahmad bin Abdul Latif al-Khatib melalui dua bukunya iaitu 'Raudat alHussab dan 'Alam al Hussab.

Kalendar dan takwim: masyarakat Jawa mempunyai sistem kalendernya sendiri yang dikenal sebagai Tarikh Aji Syaka yang berdasarkan kepada pergerakan matahari. Pengiraan takwim ini kemudiannya ditukar kepada berdasarkan pengiraan bulan pada tahun 1555.

Di samping perkembangan sistem matematik subur di kalangan ilmuan Islam di institusi pondok, masyarakat Melayu kebanyakan juga mempunyai sistem pengukuran tersendiri yang digunakan dalam kehidupan seharian. Sistem pengukuran ini lebih berdasarkan kepada penggunaan alam sebagai asas pengukuran kerana eratnya hubungan mereka dengan alam persekitaran. Terdapatnya pengiraan atau pengukuran berdasarkan tangan, seperti hasta, jengkal, depa untuk mengukur jarak atau keluasan dan lilitan sesuatu benda. Bagi ukuran jengkal, jarak yang dijadikan asas ialah jarak antara penghujung ibu jari dengan penghujung jari hantu dalam keadaan tangan terbuka. Bagi ukuran depa pula jaraknya ialah antara buku siku dengan penghujung jari hantu.

Bagi benda yang berbidang atau berkeluasan diukur berdasarkan konsep bidang atau kajang atau helai. Ukuran untuk tanah ada sistemnya sendiri seperti bidang, jemba, relung dan sebagainya. Ukuran bagi benda yang bertangkai atau panjang didasarkan kepada gugusan atau ikatan. Ukuran bagi benda-benda yang panjang dan bulat didasarkan kepada boleh atau tidak benda itu dipeluk. Misalnya untuk mengukur besar kecilnya sesuatu pohon kayu akan diukur berdasarkan badan manusia. Terdapatnya anggaran badan seperti sepemeluk atau dua pemeluk merujuk kepada pohon kayu yang diukur. Pohon kayu yang besar sering dirujuk sebagai dua pemeluk yang menggambarkan besarnya pohon pokok tersebut sebesar pemelukan dua orang manusia.

Mereka juga menggunakan ukuran pelaung untuk mengukur jarak dari satu tempat ke satu tempat dengan diasaskan oleh sejauh sepelaungan suara yang dapat disuarakan manusia. Terdapat istilah sepelaung, dua pelaung atau seterusnya bagi menunjukkan jarak sesuatu tempat itu. Bagi jarak yang lebih jauh istilah sepenanak 
digunakan yang merujuk kepada masa menanak nasi yang biasanya diambil bagi menunjukkan pengukuran masa bagi perjalanan ke sesuatu destinasi. Jarak atau sela masa yang lebih lama akan menggunakan pengukuran berdasarkan bulan atau purnama seperti sepurnama, dua purnama dan seumpamanya.

Asmah $\mathrm{Hj}$ Omar dalam kajiannya ke atas budaya dan penglibatan dunia orang Melayu dalam konsep bilangan menerangkan orang Melayu telahpun mempunyai konsepsi terhadap bilangan seperti mencampur, menolak, mendarab, bahagi, dan konsep perpuluhan sebelum kedatangan pengaruh asing ke alam Melayu (Asmah Hj. Omar, 1986). Kemam-puan membilang ini dapat dibuktikan melalui cara orang Melayu mencampur seperti konsep sebelas hingga sembilan belas. Apa yang berlaku ialah percampuran iaitu 11 ialah 1 (se) campur 10; 12 ialah 2 campur 10 dan seterusnya. Sebaliknya dalam jumlah 8 dan 9 terdapat konsep penolakan. Hal ini tidak dapat difahami tanpa melihat kepada etimologi atau sejarah pertumbuhan perkataanperkataan itu sendiri. Perkataan lapan adalah kependekan dari delapan yang berkembang daripada dua alapan. Kata alap dalam bahasa Jawa dan banyak bahasa Austronesia lainnya bererti 'ambil'. Jadi dua alapan bermakna 'diambil dua' - yakni 'sepuluh diambil dua'- dengan titik tolak dari 10. Untuk sembilan cara menerbitkannya sama dengan delapan dari segi psikologinya, iaitu menolak dari sepuluh. Dalam hal ini yang ditolak adalah satu dan perbuatan tolak itu diwahanakan oleh kata dalam bahasa Melayu sendiri, iaitu ambil; jadi se + ambilan bermakna 'diambil satu (se) daripada sepuluh'. Dalam proses pembentukan kata itu bunyi vokal e pada awalan se-itu digugurkan (Asmah Hj. Omar, 1986).

Jumlah sepuluh merupakan satu titik tolak yang penting dalam penjumlahan. Jumlah ini juga penting dalam pendaraban seperti yang tergambar dalam konsep sepuluh (1 $\times 10)$, dua puluh $(2 \times 10)$ dan seterusnya. Ini menunjukkan bahawa konsep pendaraban itu tidak datang dengan kebudayaan asing tetapi sudah sedia ada dalam kebudayaan Melayu (Asmah Hj. Omar, 1986). Manakala konsep yang didukung oleh ratus dan ribu pula seasal dengan atus, hatus, iwu, riwu dan rivu dalam bahasa-bahasa Austronesia juga telah ada dalam alam Melayu. Kedatangan pengaruh asing seperti melalui bahasa Sanskrit memperkayakan bahasa Melayu dalam memberikan konsep penjumlahan yang sudah pun dikenali seperti keti (=sepuluh ribu), laksa (=seratus ribu) dan juta (=seribu-ribu) (Asmah Hj. Omar, 1986). Konsep pecahan juga sudah ada dalam bahasa Melayu sebelum kemasukan pengaruh asing. Dalam jumlah yang terhad, iaitu konsep setengah atau separuh dan suku. Sebenarnya paruh dalam separuh itu adalah dari bahasa Jawa paro yang bermakna dijadikan dua atau diperduakan. Konsep suku timbul dari ungkapan sesuku dan tiga suku. Suku bermakna bahagian dari pada sesuatu yang lebih besar (Asmah Hj. Omar, 1986).

Selain itu terdapat juga istilah pengukuran yang tertentu dalam mengukur sesuatu seperti mengukur cecair dan biji-bijian menurut benda pengisinya seperti semangkuk air/nasi, secupak padi, segantang beras, setakar gandum dan seumpamanya. 
Istilah-istilah ini digunakan dengan meluasnya dalam masyarakat Melayu sejak beratus tahun yang silam. Penggunaan segala istilah ini bukan menunjukkan orang Melayu tidak mementingkan pengiraan atau pengukuran yang tepat tetapi sebaliknya menunjukkan kepekaan mereka untuk mengaitkan alam persekitaran dengan kehidupan mereka. Dengan kata lain mereka menggunakan istilah yang mudah untuk difahami jika melibatkan hal-hal atau urusan pekerjaan yang dianggap tidak memerlukan pengiraan yang terlalu terperinci. Bagaimanapun apabila melibatkan hal-hal kehidupan yang bersangkutan urusan agama, perniagaan dan keilmuan, masyarakat Melayu akan menggunakan segala ilmu matematik yang kompleks yang telah dipelopori oleh ilmuan atau ulama tempatan tadi.

\subsection{KIMIA (PELEBURAN LOGAM)}

Kemampuan orang Melayu dalam bidang kimia berkait rapat dengan keperluan untuk menyediakan keperluan material bagi kegunaan harian dan juga sebagai simbol kerajaan Kesultanan Melayu. Mereka ini memiliki kepandaian untuk melakukan peleburan dengan menerima teknik peleburan dari generasi sebelumnya. Aktiviti ini dikenal sebagai proses penciptaan logam hasil peleburan tembaga, besi, emas dan perak. Pada zaman silam keperluan kepada bidang ini muncul sesuai dengan kehendak sistem politik pada masa itu yang meletakkan barangan tertentu seperti periuk, dulang, mangkuk, pinggan, cawan dan sebagainya yang diperbuat daripada logam bernilai tinggi seperti emas atau perak yang juga sebagai simbol diraja dan kuasa (Mohd Taib Osman, 1988). Selain itu keperluan untuk barangan perhiasan yang tinggi nilainya seperti emas, perak dan permata menyumbang kepada kemahiran menghasilkan cincin, gelang, rantai, mahkota dan lain-lain.

Barang-barang logam ini juga mendapat permintaan yang tinggi daripada masyarakat yang menggunakannya untuk keperluan harian atau keperluan tradisi. Keperluan tradisi yang penting sekali ialah alat mempertahankan diri seperti keris dan alat senjata penting yang lain seperti tombak, pedang dan meriam.

Bagi keperluan domestik pula terdapat peralatan seperti periuk, dulang, tempat bara, tempat sirih, bekas air mawar, kaki dian, ketur atau tempat ludah, ceper dan dulang yang berkaki. Barangan tersebut penting dalam kehidupan harian juga upacara tertentu seperti menyambut kelahiran, perkahwinan dan kematian.

Masyarakat Melayu berkemahiran melakukan teknik peleburan dan penghasilan material logam melalui kaedah peleburan dan penuangan. Antara hasil peleburan yang sering dilakukan ialah peleburan dan penuangan logam tembaga yang terdiri daripada aloi kuprum dan timah yang berdasarkan kaedah penuangan lilin lesap (Wan Ramli Wan Daud, 1995).

Proses melakukan peleburan melibatkan beberapa langkah. Secara ringkas proses itu digambarkan seperti berikut: pertama, membuat acuan yang terdiri daripada kayu yang dilumur dengan lilin cair dan setelah beku acuan ini dilarik dengan bindu. Lapisan lempung dikenakan pada permukaan lilin dan lubang untuk penuangan 
tembaga lebur, dan lubang untuk penaikan tembaga ditambah. Acuan lempung ini dipanaskan untuk menguatkannya dan untuk meleburkan lilin di dalamnya. Tembaga pula akan dilebur dalam sebuah kui atau mangkuk pijar yang diletakkan dalam rakmo dalam tanah dan dihembus dengan penghembus musang. Tembaga cair yang panas dituang ke dalam acuan dan dibiarkan seketika. Setelah tembaga menjadi pepejal, acuan tanah liat dipecah untuk menghasilkan barang tembaga. Selain barang tembaga, barang perak juga dihasilkan dengan kaedah yang hampir sama dengan beberapa penambahan proses tertentu kerana melibatkan logam yang berbeza.

\subsection{KESIMPULAN}

Pencapaian masyarakat Melayu dalam bidang sains begitu menggalakkan sekali. Pencapaian yang dikemukakan di atas terbatas kepada hasil-hasil kebudayaan masyarakat Melayu tradisional. Masyarakat Melayu telah memiliki sistem perubatannya sendiri yang hingga kini masih diterima oleh sebahagian besar masyarakat Melayu. Sesuai dengan tahap kemodenan hari ini sebahagian besar ramuan ubatan tradisi ini telah dibungkus dalam bentuk yang lebih menarik dan selamat. Ahli sains tempatan pada masa ini misalnya telah membangunkan semula ubat-ubatan tradisional kepada bentuk yang lebih moden, bersih dan terjamin keselamatannya.

Dalam bidang matematik, peranan para ulama silam amat penting dalam perkembangan ilmu matematik dan astronomi dalam masyarakat Melayu. Walaupun di kalangan masyarakat biasa sistem matematik menggunakan sistem yang mudah tetapi telah berlaku beberapa perkembangan dalam pencapaian matematiknya hingga memungkinkan beberapa tokoh matematik muncul di alam Melayu. Sumbangan yang tidak dapat dinafikan ialah peranan institusi pendidikan di alam Melayu iaitu pendidikan pondok, pesantren, madrasah, surau dan Jamiah (Universiti) dalam melahirkan ahli matematik dan astronomi Melayu.

Semua pencapaian ini menjadi pemangkin kepada usaha Malaysia hari ini untuk menuju negara maju sesuai dengan wawasan 2020. Ia menjadi bukti keupayaan masyarakat Melayu dalam bidang sains kerana budaya sains telah pun mengakar sejak zaman tradisional lagi. Tentunya konsepsi sains tradisional itu tidak menyamai konsepsi sains moden hari ini kerana beberapa batasan dan kelemahan. Bagaimanapun ia bukanlah menjadi satu bukti kelemahan sebaliknya ia menunjukkan walaupun masyarakat Melayu ketika itu agak ketinggalan tetapi pencapaian mereka dalam bidang sains tidaklah terlalu ketinggalan. Penting sekali kejayaan masyarakat Melayu tradisi dalam bidang sains diwar-warkan kepada generasi hari ini untuk membina jatidiri dan keyakinan tentang keupayaan mereka menguasai ilmu penting ini. Masyarakat Melayu sebenarnya mengongsi kejayaan umat Islam lampau yang pernah menjadi pelopor sains dunia kerana tamadun Islam yang pernah gemilang itu merupakan tamadun yang dibina oleh semua penganut agama ini. Lantaran itu kejayaan pengusaan ilmu sains bukanlah sesuatu yang mustahil sebagaimana dibuktikan hari ini melalui 
kejayaan beberapa sarjana Melayu-Islam dalam pencapaian sains yang berada di Institusi pengajian tinggi negara ini.

\section{BIBLIOGRAFI}

Abdul Razak bin Salleh. 2000. "Sukatan Dalam Budaya Melayu Sebelum Abad Ke-20”. dalam Kesturi: (Jurnal Akademi Sains Islam Malaysia (ASAS). 10(1\&2): 1-40.

A. Samad Ahmad. 1988. Warisan Perubatan Melayu. Kuala Lumpur: Dewan Bahasa dan Pustaka.

Aishah Haji Muhammad. 1998. Tabiat Makan, dalam Wan Hashim Wan The dan Ismail Hamid (eds.). Nilai Budaya Masyarakat Desa; Kajian Etnografi di Wang Kelian, Perlis. Jilid 1, Kuala Lumpur: Dewan Bahasa dan Pustaka.

Asmah Haji Omar. 1986. Bahasa dan Alam Pemikiran Melayu. Kuala Lumpur: Dewan Bahasa dan Pustaka.

Abdul Rahman Ismail. 1985. Kewibawaan Mutlak Raja dan Ketaatsetiaan Mutlak Rakyat Kepada Raja: Satu Penilaian semula Tentang Lunas Perhubungan Raja-Rakyat Masyarakat Melayu Tradisional Seperti Yang terdapat Dalam Kitab-Kitab Sastera Sejarah Melayu. Kajian Malaysia 111. m.s. 32-57.

Hashim Awang A. R. 1990. Pengantar Antropologi Perubatan. Kuala Lumpur: Dewan Bahasa dan Pustaka.

Mohd Taib Osman. 1977. "Perbomohan: Satu Aspek World View Dalam Budaya Melayu” dalam Zainal Kling (ed.). Masyarakat Melayu: Antara Tradisi dan Perubahan. Kuala Lumpur: Utusan.

Mohd Taib Osman. 1988. Bunga Rampai: Aspects of Malay Culture. Kuala Lumpur: Dewan Bahasa dan Pustaka.

Mat Rofa bin Ismail. 1996. "Pembudayaan Matematik Dalam Gugusan Kepulauan Melayu”, dalam Mohd Yusuf Hj. Othman (ed.). Siri Wacana Sejarah dan Falsafah Sains. Jilid 5. Kuala Lumpur, Dewan Bahasa dan Pustaka.

P. E. De Josselin De Jong. 1964. "The Character of Malay Annals”, dalam John Bastin \& R.Roalvick (eds.), Malayan and Indonesian Studies. London: Oxford University Press.

Richard Winstedt. 1981. The Malay-a Cultural History. Singapore: Graham Brash.

R. J. Wilkinson (ed.). Paper On Malay Subjects. London: Oxford University Press.

Wan Fuad Wan Hassan. 1996. Ringkasan Sejarah Sains. Kuala Lumpur: Dewan Bahasa dan Pustaka.

Wan Ramli Wan Daud. 1995. "Sejarah Perkembangan Teknologi Melayu Satu Kajian Awal”, dalam Mohd. Yusof Hj. Othman (eds.). Siri Wacana Sejarah dan Falsafah Sains. Jilid 4, Kuala Lumpur: Dewan Bahasa dan Pustaka.

Zhari Ismail dan Norhayati Ismail. 1995. "Ubat-ubatan Melayu Tradisi masa Kini dan Prospek Pada Masa Hadapan”, dalam Ismail Hussein (ed.). Tamadun Melayu Jilid 5. Kuala Lumpur: Dewan Bahasa dan Pustaka. 
